\title{
Göte Turesson's research legacy to Hereditas: from the ecotype concept in plants to the analysis of landraces' diversity in crops
}

\author{
Rodomiro Ortizi]
}

\begin{abstract}
Hereditas began with articles on plants since its first issue in May 1920 (six out of eight) and continued with more original articles (43\% of the total of this journal) on plants (of which $72 \%$ of those in plants were on crops) until today. In December 1922, the 140-page article The Genotypical Response of the Plant Species to the Habitat by evolutionary botanist Göte Turesson (Institute of Genetics, Lund University, Åkarp, Sweden) became available. This publication shows that plant phenology has a genetic basis and may ensue from local adaptation. As a result of this research involving various plant species, Turesson elaborated further in this article his term ecotype "as an ecological sub-unit to cover the product arising as a result of the genotypical response of an ecospecies to a particular habitat." Although plant articles included in Hereditas involved from its beginning, trait inheritance, mutants, linkage analysis, cytology or cytogenetics, and more recently gene mapping and analysis of quantitative trait loci with the aid of DNA markers, among others, since the mid-1980s several publications refer to the population biology of plant landraces, which are locally grown cultivars that evolved over time by adapting to their natural and cultural environment (i.e., agriculture), and that may become isolated from other populations of the same crop. This article provides a briefing about research on plant science in the journal with emphasis on crops, summarizes the legacy to genetics of Göte Turesson, and highlights some landrace diversity research results and their potential for plant breeding.
\end{abstract}

Keywords: Agamospecies, Breeding, Ecotype, Genecology, Landrace, Population genomics

\section{Plant and crop science in $\mathbf{1 0 0}$ years of Hereditas}

The beginnings of Hereditas are tied to plants and the Mendelian Society in Lund (Skåne, Sweden) as indicated by Höglund and Bengtsson [1]. The Mendelian Society in Lund (whose founding was on 10th December 1910) decided in 1920 to launch a journal on genetics aiming a broad audience. The fund raising involved the plant breeding sector that agreed having such a journal could provide knowledge for developing new crops and cultivars. English, French and German were the languages used in

\section{Correspondence: rodomiro.ortiz@slu.se}

Department of Plant Breeding, Swedish University of Agricultural Sciences, Sundsvagen 10 Box 101, SE 23053 Alnarp, Sweden the early articles, including those of its first issue in May 1920. There were eight articles, of which $3 / 4$ were on plants. The famous geneticist Herman Nilsson-Ehle (1879-1949) [2], then working at at the Institute of Genetics of Lund University in Åkarp (Skåne, Sweden), was the author of the first article focusing on the inheritance of host plant resistance in barley (Hordeum vulgare) cultivars to the cyst nematode Heterodera schachti [3]. The other five plant articles in the first issue of this journal were on studying the inheritance of characteristics in Oenothera Lamarckiana, which in the early years of the 1920s was becoming an important model species for studying genetics and evolution, Papaver laevigatum, pea (Pisum sativum) and onion 
(Allium серa); as well as spelt-like bud sports (mutations) in bread wheat (Triticum aestivum). Two years later, a 140page article The Genotypical Response of the Plant Species to the Habitat (Fig. 1) by evolutionary botanist Göte Turesson (Institute of Genetics, Lund University, Åkarp, Sweden) brought the term ecotype to define a group of plants resulting from their genotypical response to a specific habitat [4].

Throughout its 100 years, Hereditas included, as shown in Fig. 2, in excess of 1800 original research articles on plant species of the wild Flora Scandinavica and Fennoscandian grassland species or trees $(43 \%$ of those included by this journal until now), of which over 1300 (72\% of the plant articles) are on many crops. It is worth highlighting that several articles are on mutations in plant breeding, whose research began by Nilsson-Ehle and Åke Gustafsson the 1920s using X-rays and UV radiation on Svalöf's barley cultivar 'Gull'. It was during the mid-1930s that valuable mutants for genetic research and breeding were developed through cooperative research between the then Institute of Genetics at Lund University and the Swedish Seed Association [5]. The Institute in Lund became a world-leading center in genetics where later former Nilsson-Ehle's pupils Arne Müntzing and Albert Levan became research leaders worldwide. The Nordiskt Generesurscenter (NordGen, Alnarp, Sweden) holds today about 11,000 morphological and physiological barley mutants that show changes in their spikes, spikelets, culm length and composition, growth type, kernel development and formation, early heading, awns, leaf blades, pigmentation, chlorophyll development and host plant resistance to powdery mildew caused by the fungus Blumeria graminis f. sp. hordei [6].

Along its history, crop articles in Hereditas' were up to date on developments in genetics, cytology and cytogenetics, as well as cell and molecular biology (Fig. 3). Various articles in this journal were related to the Allium test [7], which is used as standard for environmental monitoring. This rapid screening test allows detecting chemicals, contaminants and other pollutants, which are regarded as hazards to the environment. The toxicity is measured by studying root growth inhibition and any adverse effects on the chromosomes of onion. This plant was selected because the ease for its storing, handling and studying both at macroscopic and microscopic levels. The root cells of onion also show the ability to activate pro-mutagens, thus broadening Allium test's applications.

The in-excess of 1800 plant original articles in Hereditas included research on at least 80 domesticated species as well as in their wild relatives. There are $57 \%$ original articles on cereals (barley, foxtail and pearl millets -Setaria italica and Pennisetum glaucum respectively, maize - Zea mays, oat - Avena sativa, rice - Oryza sativa, rye - Secale cereale, sorghum - Sorghum bicolor, tef - Eragrostis tef, triticale - Triticosecale, wheat - including both bread and durum or Triticum turgidum conv. durum), 12\% on pulses
(Adzuki bean - Vigna angularis, bean - Phaseolus vulgaris, broad bean - Vicia faba, chickpea - Cicer arietinum, lupins - Lupinus spp., mung bean - Vicia radiata, pea), $11 \%$ on grass and legume forages (Bahiagrass - Paspalum spp., Bermuda grass - Cynodon dactylon, bromes - Bromus spp., clovers - Trifolium spp., cock's foot - Dactylis glomerata, creeping Bentgrass - Agrostis spp., fescues - Festuca spp., Kentucky's bluegrass - Poa pratensis, lucerne or alfalfa - Medicago sativa, ryegrass - Lolium spp., signal grass Brachiaria spp., timothy grass - Phleum spp.), $8 \%$ on vegetables (Brassica spp., lettuce - Lactuca sativa, onion, peppers - Capsicum spp., spinach - Spinacia oleracea, table beet - Beta vulgaris, tomato - Solanum lycopersicum), 4\% on oil crops (various Brassica species, flax - Linum usitatissimum, noug - Guizotia abyssinica, poppy seed oil - Papaver somniferum, safflower - Carthamus tinctorius, sesame - Sesamum indicum, sunflower - Helianthus annuus, white mustard - Sinapsis alba), 3\% on temperate fruit (apple - Malus domestica, apricot - Prunus spp., fig - Ficus carica, grape - Vitis vinifera, pear - Pyrus spp.) and berry crops (currants - Ribes spp., Fragaria spp., Rubus spp., sweet cherry - Prunus avium, Vaccinium spp. including cranberry $-V$. oxycoccos), $2 \%$ on root (cassava - Manihot esculenta, cocoyam - Xanthosoma sagittifolium, enset Ensete ventricosum, sugar beet - Beta vulgaris spp. vulgaris Altissima Group, sweetpotato - Ipomoea batatas) and tuber (amochi - Arisaema schimperianum, potato - Solanum tuberosum) crops, and the remaining between both tropical fruit crops (avocado - Persea americana, banana/plantain Musa spp., cacao - Theobrema cacao, Passiflora spp., pineapple - Ananas comosus, watermelon - Citrillus lanatus) and aromatic, fibre, fuel, medicinal or recreational plants (e.g. coffee - Coffea arabica, cotton - Gossypium spp., hop - Humulus lupulus, jute - Corchorus spp., kenaf - Hibiscus cannabinus, Phalaris spp., tea - Camellia sinensis, switchgrass - Panicum virgatum, tobacco - Nicotiana spp.).

\section{Gote Turesson's ecotype, genecology and agamospecies concepts}

The evolutionary botanist Göte Turesson (Malmö, Sweden 6 April 1892 - Uppsala, Sweden 30 December 1970) introduced the concept of ecotype (based on his research of 20 species from 13 genera) while finishing his $\mathrm{PhD}$ education at Lund. Turesson understood that the characteristics in a population from natural habitats are both adaptive and hereditary stable. It is worth highlighting that an ecotype does not have a taxonomic rank because individuals from one population are capable of interbreeding with those coming from other population(s), irrespective of the genetic divergence among them. Ecotypes may vary gradually due to adaptive changes; i.e., a cline or the measurable gradient of variation for a characteristic across a geographical range of a species. For example, wild emmer (Triticum diccocoides) types showing early heading seems to adapt well in warm 


\title{
THE GENOTYPICAL RESPONSE OF THE PLANT SPECIES TO THE HABITAT
}

\author{
BY GÖTE TURESSON
}

INSTITUTE OF GENETICS, AKARP, SWEDEN

$\mathrm{T}$ HE study of the variability of the plant species in relation to its environment, or its habitat, might be pursued along two lines of research, viz. the study of the effect of various environmental factors upon the individual plant; and the study of the effect of these environmental factors upon the genotypical composition of a species-population in a certain habitat. The one line of research is primarily a study of the modifications of the plant, the other is manifestly a study of the hereditary variations. The two groups of variation have long ago been dealt with from the point of view of the environment, but while the experimental study of the former problem has received much attention the latter problem, the hereditary variation of wild plants in relation to habitat, has remained experimentally almost unattacked.

The classical transplantation experiments with Lowland plants in Alpine situations performed by Kernen (1891) and Bonnier (1895) belong to the important body of facts relating to the modifications of plants. The modern study of the problem is particularly connected with the names of KLebs $(1903,1906)$ and Goebel $(1908,1913)$. Our knowledge of the power of modification, or rather of the range of possible reactions, of the plant when exposed to different environmental factors has been greatly increased by all this work. Its important bearing upon other lines of studies has also been felt, and the data obtained through the experimental inquiries into this field have been extensively employed when attempts have been made to throw light upon less known subjects, especially in the field of ecology. This is particularly true of the cases in which the supporters of the theory of the inheritance of acquired characters endeavour to find new support for the theory in the increasing mass of data obtained (WArming, 1909, p. 373; Wiesnen, 1913, p. 314). That the fact of the great pplasticity of the plant has led to undue generalizations even in matters of a less speculative nature will be evident from

Hereditas $I I$.

Fig. 1 First page of Göte Turensson article in Hereditas in which was defined with details the term ecotype

and dry sites while those with late heading adapt better in cool and humid sites [8]. Vernalization and earliness are related to heading date in this plant, which highlights the importance of both characteristics for eco-geographical adaptation in this wild relative of wheat. Turensson's research also demonstrates the genetic basis of periodic cycle events or phenology in plants. Further analysis with DNA markers shows that wild emmer diversity is adaptive due to natural selection and may be influenced by ecological factors [9]. Natural selection was also advocated to 



Fig. 2 Total number of original articles as well as in wild plant species and crops over decades in the first 100 years of Hereditas

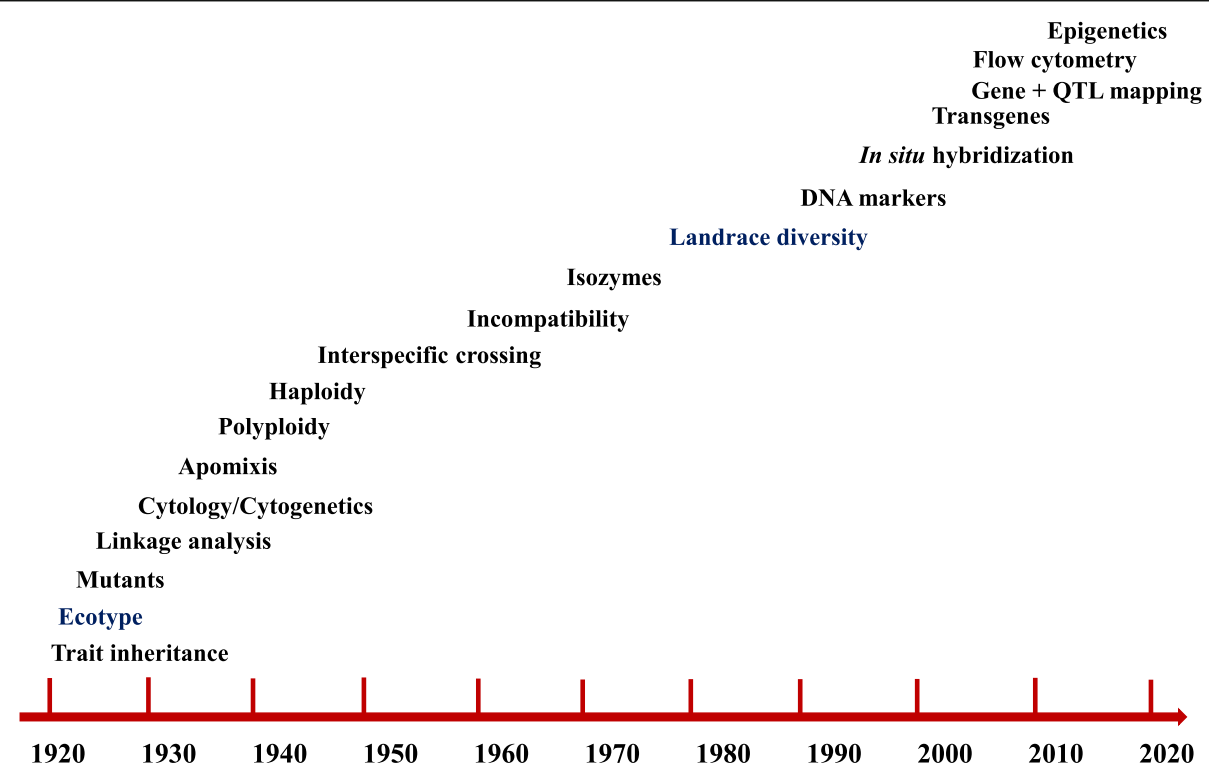

Fig. $\mathbf{3}$ Research topics (as per their first original articles) in crops in the first 100 years of Hereditas 
explain phenotypic trait variability when comparing wild barley (Hordeum spontaneum) among core and peripheral populations from Israel and Turkmenistan [10]. Likewise, allozyme variation was noted to vary and show genetic structuring in populations of the wild grass Elymus caninus from Denmark, Finland, Iceland, Italy, Norway, Sweden, Russia, China and Pakistan according to their provenance [11]. This sample of research findings vindicates Turesson's concept of ecotypes in evolution and the role of natural selection in plant adaptation. A very recent resequencing of 1506 sunflower accessions of non-recombining haplotype blocks associated with many ecologically relevant traits, as soils and climates [12] supports ecotypic differentiation. Divergent haplotype blocks often associated with structural variants maintain adaptive alleles together.

Turesson defined what became known as genecology [13], which refers to the study of genetic variation of the population distribution in a defined environment of both species and communities. In his view, the study of the hereditary variation within species in relation to the habitat was necessary because ecology, until then, did not realize the importance of such variation. His work clearly shows that differentiation among plant populations depends on their genetics rather than on plasticity or the phenotypic changes occurring as a response to the environments where they grow [14]. His research highlights, therefore, that genotype rather than morphology or habitat explains why a plant adapts to an environment [15]. Turesson further argued that the climate affects biotype distribution within a species, as well as that different climatic regions may include genotypically distinct biotype groups [16]. As noted by Heywood [17], Turesson's genecological hierarchy (which includes ecotypes or ecological races adapted to particular environments, ecospecies consisting of ecotypes, and coenospecies comprising the total ecological potential of a species) was used later by Harlan and de Wet [18] for developing the gene pool concept and its use in plant breeding based on the degree of relatedness between the crop and its wild relatives.

His investigations, which brought new lines of research and have been widely acknowledged elsewhere [19-22], were based mostly on field observations after collecting trips within Sweden, Siberia and North America, among others, and the analysis of empirical data from the experimental garden [23]. Turesson used cock's foot ecotypes (after collecting them in Siberia during 1927 and testing years later along with two other cultivars at Weibullsholm Plant Breeding Station, near Landskrona, west coast of Sweden) to study agronomic characteristics of "wild type material from which man draws when he improves' a species population to suit his needs." [24] His cock's foot research findings were validated by Stapledon [25], after working with a biotic factor such as "man's control of his grazing animal."
Turesson's first research article explains how the slope exposures influences the distribution of the evergreen conifer Douglas fir (Pseudotsuga menziesii) in the arid areas of the state of Washington (USA) [26], where he did his BSc and MSc education. He also brought, after his research on various apomictics including the grass sheep fescue (Festuca ovina) and the perennial herbaceous mouse-ear hawkweed (Pilosella officinarum), the concept of agamospecies; i.e., natural populations of plant species lacking sexual reproduction whose constituents have a common origin [27]. Turesson was also involved in developing induced tetraploids of red clover (Trifolium pratense), which was among the first products of economic importance.

\section{Landrace diversity and potential for plant breeding}

Endashew Bekele, then affiliated with the Department of Genetics at Lund University, wrote in 1985 for Hereditas the article The biology of cereal land race populations [28], in which he described the patterns of variation of barley, durum and bread wheat. His interest was on developing an evolutionary approach for plant genetic resources conservation and utilization. He proposed a hierarchical approach for defining centers of diversity for both composite populations of landraces and their pests. Bekele indicated that landraces vary along a given ecological gradient due to coadaptation or competition resulting from the effects of both multi-locus genetic organization and environmental factors. The different multi-locus structures co-evolving with those of their pathogens across regions are without doubts of high interest for plant breeding. Indeed, latitudinal clines of host plant resistance and differential selective pressures at different sites owing to their respective ecological conditions were noted among barley and the fungus Pyrenophora teres causing net blotch in this crop [29]. This knowledge may further assist on deploying effectively host plant resistance in farming systems. Moreover, as noted by Dwivedi et al. in a recent up to date review on the subject [30], landraces' genes provide means for both increasing edible yields and improving adaptation to stress-prone sites. Hence, it was not surprising to read in Hereditas several research articles since the mid-1980s about genetic differentiation among composite or landrace populations related to agro-ecological zones or geography (Table 1), thus following on and enlarging Turesson's research as illustrated in above paragraphs. Most of these articles -often written by former PhD students affiliated with either Addis Ababa University (Ethiopia) or the Swedish University of Agricultural Sciences- were on cereals and particularly from Ethiopian gene pools of crops originating or showing a high diversity in this country, e.g. barley, durum and bread wheat, sorghum or tef. These findings give hopes for an evolutionary plant breeding approach, in which highly genetically diverse crop populations are left 
Table 1 A sample of composite cross and landrace diversity analysis for crops in Hereditas

\begin{tabular}{|c|c|c|}
\hline Crop & Finding & Reference \\
\hline \multirow[t]{3}{*}{ Barley } & $\begin{array}{l}\text { Significant geographical differentiation associated with selection pressures among subpopulations in } \\
\text { a composite cross (CCXXI) - as shown by isozyme markers- which increases as generations advance }\end{array}$ & [31] \\
\hline & $\begin{array}{l}\text { Lacking significant differences for phenotypic diversity (except for aleurone color out of six characteristics) } \\
\text { either among } 10 \text { regions or among altitudes }(<2000->3501) \text { as well as among agro-ecozones but } \\
\text { most of the variance attributed to populations in } 51 \text { landrace accessions from Ethiopia }\end{array}$ & {$[32]$} \\
\hline & $\begin{array}{l}\text { High morphological variation within } 10 \text { regions and altitudes (particularly above } 2000 \mathrm{~m} \text { a.s.l.) in Ethiopia. } \\
\text { Clustering of accessions did not show grouping on the basis of regions of origin }\end{array}$ & [33] \\
\hline Wheat & $\begin{array}{l}\text { The variation of } 13 \text { qualitative or quantitative morphological characters of } 293 \text { tetraploid and hexaploid } \\
\text { wheat landraces diverged from region to region in Ethiopia. Some of these characters had a localized } \\
\text { concentration while others lack a clear distribution pattern. Likewise, a clinal variation pattern was } \\
\text { noted for host plant resistance to powdery mildew; i.e., increasing resistance frequency from north } \\
\text { to south and Arussi-Bale Highlands showing a concentration of intermediate resistance }\end{array}$ & [34] \\
\hline \multirow[t]{2}{*}{ Durum wheat } & $\begin{array}{l}\text { The first axis of a principal component analysis demonstrated that morpho-physiological variation was } \\
\text { related to weather variables affecting drought and heat stress in germplasm from Ethiopia and Syrian } \\
\text { germplasm, and to maximum temperatures in germplasm from Turkey }\end{array}$ & [35] \\
\hline & $\begin{array}{l}\text { Spike density was the only characteristic showing significant differences among Ethiopian regions for } \\
27 \text { landrace populations (being lax spikes noted frequently in Gojam), while glume color and beak } \\
\text { length changed significantly } \\
\text { according to altitude }\end{array}$ & {$[36]$} \\
\hline \multirow[t]{4}{*}{ Sorghum } & $\begin{array}{l}\text { Compact panicles frequently found in relatively dry regions, whereas loose panicles were widely noted } \\
\text { in relatively wet and humid regions, thus showing the adaptive significance of panicle compactness } \\
\text { and shape }\end{array}$ & {$[37]$} \\
\hline & $\begin{array}{l}\text { Significant allele frequency differences among } 48 \text { accessions from } 13 \text { regions of origin and } 3 \text { adaptation } \\
\text { zones (lowlands, intermediate and highlands) in Ethiopia. A Nei's unbiased genetic distance resulting } \\
\text { dendrogram constructed as well as the biplot of the first two principal components distinguished three } \\
\text { regions. Gene flow was high among adaptation zones }\end{array}$ & [38] \\
\hline & $\begin{array}{l}\text { A higher proportion of Ethiopian landraces sharing similar altitude classes and similar ecosites were } \\
\text { grouped together after cluster analysis based on ordinal variables. Panicle compactness and shape } \\
\text { contributed relatively more than other characteristics to altitudinal and ecological differentiation, } \\
\text { thus showing the adaptive significance of both characteristics }\end{array}$ & [39] \\
\hline & $\begin{array}{l}\text { The clustering from the analysis of molecular variance on } 27 \text { accessions was based on four ethnic groups } \\
\text { (Soli, Chikunda, Lozi and Tonga), which are associated with collecting sites in Zambia. Most accessions } \\
\text { were thus grouped according to their collecting sites. }\end{array}$ & {$[40]$} \\
\hline Tef & $\begin{array}{l}60 \text { Ethiopian populations (comprising } 3000 \text { lines) showed significant regional variation for } 10 \text { ( } 59 \% \text { of total } \\
\text { evaluated) quantitative traits. Significant clinal variation among altitudes for only six }(35 \%) \text { of these traits. } \\
\text { Such results suggest that peasants across regions grow different agro-pheno-morphic types irrespective } \\
\text { of altitude }\end{array}$ & {$[41]$} \\
\hline Amochi & $\begin{array}{l}\text { Analysis of molecular variance -based on } 167 \text { amplified fragment length polymorphic loci scored from four } \\
\text { primer pair combinations split } 70.5,16.7 \text { and } 12.8 \% \text { of the variability between altitudes, as well as between } \\
\text { and within populations, respectively, in this Ethiopian tuberous crop }\end{array}$ & {$[42]$} \\
\hline Noug & $\begin{array}{l}\text { Genetic distances based on microsatellites were smaller between populations of neighboring regions in this } \\
\text { Ethiopian oil crop, thus placing the UPGMA clustering the populations from neighboring regions closer than } \\
\text { those from farther apart areas, and keeping the contiguity of these regions }\end{array}$ & [43] \\
\hline
\end{tabular}

to the forces of natural selection that favor plants contributing more seed to the next generation than those with low fitness where they grow.

Turesson's genecology and ecotype concepts also provided the foundation for developing the Focused Identification of Germplasm Strategy (FIGS), which allows identifying genebank accessions bearing target traits according to geographic information and agro-climatic knowledge of their collecting sites. FIGS' underpinnings are related to the fact that environments influence natural selection, thus shaping the geographical distribution of landraces and crop wild relatives. This sampling approach leads to forming 'best-bet' trait-specific subsets of genebank accessions, thus facilitating the finding of adaptive characteristics (and their controlling genes) of interest because the probability of success increases as noted, for example, for host plant resistance to Russian wheat aphid [44], or powdery mildew in wheat [45], or drought tolerance in faba bean [46], among others. Incorporating genomics and phenotyping data into a FIGS approach may facilitate identifying alleles from broad genebank holdings. As noted in maize [47, 48] genomic regions controlling time flowering and grain yield were related to adaptation, and the former associated to 
altitude, while genetic footprints were defined by regions under selection in wheat [49]. Understanding such landrace diversification assists also on breeding new cultivars sustainably since it provides insights regarding crop evolution across stress-prone environments, and for finding genebank accessions and other germplasm whose allelic diversity may be missing in today's breeding programs.

\section{Conclusion}

Genebank accessions originate mostly from collecting sites (farms or natural habitats) where they evolved over time, thus showing adaptive traits that were shaped by the selection pressures therein. For example, multi-genic analysis of quantitative traits in maize revealed that flowering time alleles are associated with elevation, which indicated that highland adaptation relates to the flowering time pathway [50]. Population genomics uses today, therefore, a large number of high-density DNA markers that are scored in genebank accessions coming from different sites to identify unusual patterns of variation resulting from selection [51]. In this regard, a global sorghum population was characterized with single nucleotide polymorphisms (SNPs) to study the crop population structure [52]. This research provided insights on the patterns of ancient sorghum diffusion to diverse agro-climatic regions across Africa and Asia, thus reinforcing that both agro-climatic constraints and geographic isolation shaped this process. Furthermore, the coupling of population genomics with quantitative genetics led to uncovering mechanisms causing adaptation, e.g. branch length seems to be an agroclimatic trait because dense panicles lead to high yielding sorghum, whereas grain loss reduces with open panicles under humidity. This knowledge led to testing the hypothesis about the feasibility of predicting phenotypic variation based on the assumption that the association between SNP alleles and landrace collecting site reflects adaptation, which was proved in sorghum landraces interacting with environments under drought or aluminum toxicity [53]. Such genomic signatures of adaptation pave the way for a cost-effective "turbo charging" of genebanks, which was demonstrated after integrating genomic prediction into a wide germplasm assessment with the aim of identifying promising sorghum accessions showing high biomass yield [54]. In this regard, after sequencing of rice's Heading date 1 (Hd1) gene, Wu et al. [55] found three haplotypes related to flowering time across environments in both landraces and modern cultivars, as well as in weedy populations. As stated by Corrado and Rao [56], such genomic scans may unlock instar-specific diversity that differs from that available in modern cultivars and resulting from human selection. Hence, the legacy to genetics of Göte Turesson translates today to using population genomics for researching both ecotype and landrace diversity, which will lead to an in situ or on farm conservation strategy, and their further use in plant breeding.

\section{Abbreviations}

FIGS: Focused Identification of Germplasm Strategy; Hd1: Heading date 1 gene in rice; SNPs: Single nucleotide polymorphisms

\section{Acknowledgments}

The authors thank Prof. Waheeb Heneen (SLU, Sweden) for comments and editing provided to an early draft of this manuscript.

\section{Author's contributions}

Conceptualization, data collection and analysis, writing - original draft and editing after getting comments and suggestions: R.O. The author(s) read and approved the final manuscript.

\section{Funding}

Not applicable. Open Access funding provided by Swedish University.

Availability of data and materials

Not applicable.

Ethics approval and consent to participate

Not applicable.

\section{Consent for publication}

Not applicable.

\section{Competing interests}

The author declares that there are no competing interests.

Received: 29 September 2020 Accepted: 28 October 2020

Published online: 07 November 2020

References

1. Höglund M, Bengtsson B. The origin of the Mendelian Society in Lund and the start of Hereditas. Hereditas. 2014;151:110-4. https://doi.org/10.1111/ hrd2.00078

2. Akerberg E. Nilsson-Ehle and the development of plant breeding at Svalof during the period 1900-1915. Hereditas. 1986;105:1-5. https://doi.org/10. 1111/j.1601-5223.1986.tb00633.x.

3. Nilsson-Ehle H. Über resistenz gegen Heterodera schachti bei gewissen gerstensorten, ihre vererbungsweise und bedeutung für die praxis. Hereditas. 1922;1:1-34. https://doi.org/10.1111/j.1601-5223.1920.tb02449.x.

4. Turesson $\mathrm{G}$. The genotypical response of the plant species to the habitat. Hereditas. 1922;3:211-340. https://doi.org/10.1111/j.1601-5223.1922.tb02734.x.

5. Lundqvist U. Scandinavian mutation research in barley - a historical review. Hereditas. 2014;151:123-31. https://doi.org/10.1111/hrd2.00077.

6. Lundqvist $U$. The Swedish collection of barley mutants held at the Nordic Genebank. Barley Genet Newslett. 2005;35:150-4.

7. Fiskesjö $\mathrm{G}$. The Allium test as a standard in environmental monitoring. Hereditas. 1985;102:99-112. https://doi.org/10.1111/j.1601-5223.1985.tb00471.x.

8. Kato K, Tanizoe C, Beiles A, Nevo E. Geographical variation in heading traits in wild emmer wheat, Triticum dicoccoides. II. Variation in heading date and adaptation to diverse eco-geographical conditions. Hereditas. 1998;128:339. https://doi.org/10.1111/j.1601-5223.1998.00033.x.

9. Dong $\mathrm{P}$, Wei Y-M, Chen G-Y, Li W, Wang J-R, Nevo E, Zheng Y-L. EST-SSR diversity correlated with ecological and genetic factors of wild emmer wheat in Israel. Hereditas. 2009;149:1-10. https://doi.org/10.1111/j.1601-5223. 2009.02098.x.

10. Volis S, Mendlinger S, Orlovsky N. Variability in phenotypic traits in core and peripheral populations of wild barley Hordeum spontaneum Koch. Hereditas. 2001;133:235-47. https://doi.org/10.1111/j.1601-5223.2000.00235.x.

11. Díaz O, Solomon B, von Bothmer R. Genetic diversity and structure in populations of Elymus caninus (L.) L. (Poaceae). Hereditas. 1999;131:63-74. https://doi.org/10.1111/j.1601-5223.1999.00063.x.

12. Todesco M, Owens GL, Bercovich N, et al. Massive haplotypes underlie ecotypic differentiation in sunflowers. Nature. 2020;584:602-7. https://doi. org/10.1038/s41586-020-2467-6.

13. Turesson G. The scope and import of genecology. Hereditas. 1923;4:171-6. https://doi.org/10.1111/j.1601-5223.1923.tb02955.x. 
14. Turesson $\mathrm{G}$. The the plant species in relation to the habitat and climate: contributions to the knowledge of genecological units. Hereditas. 1925;6: 147-236. https://doi.org/10.1111/j.1601-5223.1925.tb03139.x.

15. Turesson G. The species and variety as ecological units. Hereditas. 1922;3: 100-13. https://doi.org/10.1111/j.1601-5223.1922.tb02727.x.

16. Turesson $\mathrm{G}$. The selective effect of climate upon the plant species. Hereditas. 1930;14:99-152. https://doi.org/10.1111/j.1601-5223.1930.tb02531.x.

17. Heywood VH. The genesis of IOPB: a personal memoir. Taxon. 2011;60:320-3.

18. Harlan JR, de Wet JMJ. Towards a rational classification of cultivated plants. Taxon. 1971;20:509-17.

19. Cockerell TDA. Ecotypes of plants. Nature. 1926;117:588. https://doi.org/10. 1038/117588a0

20. Turrill WB. The ecotype concept. A consideration with appreciation and criticism, especially of recent trends. The New Phytologist. 1946;46:34-43. https://doi.org/10.1111/j.1469-8137.1946.tb05044.x.

21. Heslop-Harrison J. New concepts in flowering-plant taxonomy. London: Heinemann; 1953.

22. Hagen JB. Experimentalists and naturalists in twentieth-century botany: experimental taxonomy, 1920-1950. J Hist Biol. 1984;17:249-70.

23. Müntzing A. Göte Wilhelm Turesson. Taxon. 1971;20:773-5. https://doi.org/ $10.2307 / 12188603$

24. Turesson G. Ecotypical selection in Siberian Dactylis glomerata L. Hereditas. 1929:335-51. https://doi.org/10.1111/j.1601-5223.1929.tb02511.x.

25. Stapledon RG. Cocksfoot grass (Dactylis glomerata L.): ecotypes in relation to the biotic factor. J Ecol. 1928;16:71-104. https://doi.org/10.2307/2255843.

26. Turesson G. Slope exposure as a factor in the distribution of Pseudotsuga taxifolia in arid parts of Washington. Bull Torrey Botanical Club. 1914;41:33745. https://doi.org/10.2307/2479615.

27. Turesson G, Turesson B. Experimental studies in Hieracium pilosella. I. Reproduction, chromosomes number and distribution. Hereditas. 1960;46: 717-36. https://doi.org/10.1111/j.1601-5223.1960.tb03112.x.

28. Bekele E. The biology of cereal land race populations. Hereditas. 1985;103: 119-34. https://doi.org/10.1111/j.1601-5223.1985.tb00491.x.

29. Rau D, Rodriguez M, Murgia ML, Balmas V, Bitocchi E, Bellucci E, Nanni L, Attene G, Papa R. Co-evolution in a landrace meta-population: two closely related pathogens interacting with the same host can lead to different adaptive outcomes. Sci Rep. 2015;12834. https://doi.org/10.1038/srep12834.

30. Dwivedi SL, Cecarelli S, Blair M, Upadhyaya H, Are AK, Ortiz R. Landrace germplasm: a useful resource for improving yield and abiotic stress adaptation. Trends Plant Sci. 2016;21:31-42. https://doi.org/10.1016/j.tplants.2015.10.012.

31. Zhang $Q$, Jana S, Saghai Maroof MA. A diagnostic analysis of genetic differentiation among subpopulations of a barley composite cross using isozyme markers. Hereditas. 1993;118:63-70. https://doi.org/10.1111/j.16015223.1993.t01-3-00063.x

32. Demissie A, Bjørnstad Å. Phenotypic diversity of Ethiopian barleys in relation to geographical regions, altitudinal range, and agro-ecological zones: as an aid to germplasm collection and conservation strategy. Hereditas. 1996;124: 17-29. https://doi.org/10.1111/j.1601-5223.2010.02173.x.

33. Abebe TD, Bauer AM, Léon J. Morphological diversity of Ethiopian barleys (Hordeum vulgare L.) in relation to geographic regions and altitudes. Hereditas. 2010;147:154-64. https://doi.org/10.1111/j.1601-5223.1995.00163.x.

34. Negassa M. Estimates of phenotypic diversity and breeding potential of Ethiopian wheats. Hereditas. 1986;104:41-8. https://doi.org/10.1111/j.16015223.1986.tb00515.x.

35. Annicchiarico P, Pecetti L, Damania AB. Relationships between phenotypic variation and climatic factors at collecting sites in durum wheat landraces. Hereditas. 1995;122:163-7. https://doi.org/10.1111/j.1601-5223.1995.00163.x.

36. Bechere E, Belay G, Mitiku D, Merker A. Phenotypic diversity of tetraploid wheat landraces from northern and north-central regions of Ethiopia. Hereditas. 1996;124:165-72. https://doi.org/10.1111/j.1601-5223.1996.00165.x.

37. Ayana A, Bekele E. Geographical patterns of morphological variation in sorghum (Sorghum Bicolor (L.) Moench) germplasm from Ethiopia and Eritrea: qualitative characters. Hereditas. 2004;129:195-205. https://doi.org/ 10.1111/j.1601-5223.1998.t01-1-00195.x.

38. Ayana A, Bryngelsson T, Bekele E. Geographic and altitudinal allozyme variation in sorghum (Sorghum Bicolor (L.) Moench) landraces from Ethiopia and Eritrea. Hereditas. 2004;135:1-12. https://doi.org/10.1111/j.1601-5223.2001.t01-1-00001.x.

39. Abdi A, Bekele E, Asfaw Z, Teshome A. Patterns of morphological variation of sorghum (Sorghum bicolor (L.) Moench) landraces in qualitative characters in north Shewa and south Welo, Ethiopia. Hereditas. 2003;137: 161-72. https://doi.org/10.1034/j.1601-5223.2002.01604.x.
40. Ng'uni D, Geleta M, Bryngelsson T. Genetic diversity in sorghum (Sorghum bicolor (L.) Moench) accessions of Zambia as revealed by simple sequence repeats (SSR). Hereditas. 2011;148:52-62. https://doi.org/10.1111/j.1601-5223.2011.02208.x.

41. Assefa K, Tefera H, Merker A. Variation and inter-relationships of quantitative traits in tef (Eragrostis tef (Zucc.) trotter) germplasm from western and southern Ethiopia. Hereditas. 2002;136:116-25. https://doi.org/10.1034/j. 1601-5223.2002.1360205.x.

42. Gedebo A, Appelgren M, Bjørnstad A, Tsegaye A. Genetic diversity and differentiation of cultivated amochi (Arisaema schimperianum Schott) in Ethiopia as revealed by AFLP markers. Hereditas. 2006;143:229-35. https:// doi.org/10.1111/j.2006.0018-0661.01951.x.

43. Petros Y, Merker A, Zeleke H. Analysis of genetic diversity of Guizotia abyssinica from Ethiopia using inter simple sequence repeat markers. Hereditas. 2007;144:18-24. https://doi.org/10.1111/j.2007.0018-0661.01969.x.

44. El Bouhssini M, Street K, Amri A, Mackay M, Ogbonnaya FC, Omran A, Abdalla O, Baum M, Dabbous A, Rihawi F. Sources of resistance in bread wheat to Russian wheat aphid (Diuraphis noxia) in Syria identified using the focused identification of Germplasm strategy (FIGS). Plant Breed. 2011;130: 96-7. https://doi.org/10.1111/j.1439-0523.2010.01814.x.

45. Vikas VK, Kumar S, Archak S, et al. Screening of 19,460 genotypes of wheat species for resistance to powdery mildew and identification of potential candidates using focused identification of germplasm strategy (FIGS). Crop Sci. 2020;60. https://doi.org/10.1002/csc2.20196.

46. Khazaei H, Street K, Bari A, Mackay M, Stoddard FL. The FIGS (focused identification of Germplasm strategy) approach identifies traits related to drought adaptation in Vicia faba genetic resources. PLoS One. 2013;8: e63107. https://doi.org/10.1371/journal.pone.0063107.

47. Romero Navarro JA, Wilcox M, Romay C, Swarts K, Trachsel S, Preciado E, Terron A, Vallejo Delgado H, Vidal V, Ortega A, Espinoza Banda A, Gómez Montiel NO, Ortiz-Monasterio I, San Vicente F, Guadarrama Espinoza A, Atlin G, Wenzl P, Buckler ES HS. A study of allelic diversity underlying flowering time adaptation in maize landraces. Nat Genet. 2017;49:476-80. https://doi.org/10.1038/ng.3784.

48. Gates DJ, Runcie D, Janzen GM, Romero Navarro A, Willcox M, Sonder K, Snodgrass SJ, Rodríguez-Zapata F, Sawers RJH, Rellán-Álvarez R, Buckler ES, Hearne $\mathrm{S}$, Hufford MB, Ross-lbarra J. Single-gene resolution of locally adaptive genetic variation in Mexican maize. bioRxiv. 2019:706739. https:/doi.org/10.1101/706739.

49. Sansaloni C, Franco J, Santos B, Percival-Almyn L, Singh S, Petroli C, Campos J, Dreher K, Payne T, Marshall D, Kilian B, Milne I, Raubach S, Shaw P, Stephen G, Carling J, Saint Pierre C, Burgueño J, Crossa J, Li H, Guzman C, Kehel Z, Amri A, Kilian A, Wenzl P, Uauy C, Banziger M, Caccamo M, Pixley K. Diversity analysis of 80,000 wheat accessions reveals consequences and opportunities of selection footprints. Nat Commun. 2020;11:4572. https://doi.org/10.1038/s41467-020-18404-w.

50. Wang L, Josephs EB, Lee KM, Roberts LM, Rellán-Álvarez R, Ross-Ibarra R, Hufford MB. Molecular parallelism underlies convergent highland adaptation of maize landraces. bioRxiv. 2020;2020:227629. https://doi.org/10.1101/2020.07.31.227629.

51. Stinchcombe JR, Hoekstra HE. Combining population genomics and quantitative genetics: finding the genes underlying ecologically important traits. Heredity. 2008;100:158-70. https://doi.org/10.1038/sj.hdy.6800937.

52. Morris GP, Ramu P, Deshpande SP, Hash CT, Shah T, Upadhyaya HD, RieraLizarazu O, Brown PJ, Acharya CB, Mitchell SE, Harriman J, Glaubitz JC, Buckler ES, Kresovich S. Population genomic and genome-wide association studies of agroclimatic traits in sorghum. Proc Natl Acad Sci USA. 2013;110: 453-8. https://doi.org/10.1073/pnas.1215985110.

53. Lasky JR, Upadhyaya HD, Ramu P, Deshpande S, Hash CT, Bonnette J, Juenger TE, Hyma K, Acharya C, Mitchell SE, Buckler ES, Brenton Z, Kresovich S, Morris GP. Genome-environment associations in sorghum landraces predict adaptive traits. Sci Adv. 2015;1:e1400218. https://doi.org/10.1126/sciadv.1400218.

54. Yu X, Li X, Guo T, Zhu C, Wu Y, Mitchell S, Roozeboom K, Wang D, Wang M, Pederson G, Tesso T, Schnable P, Bernardo R, Yu J. Genomic prediction contributing to a promising global strategy to turbocharge gene banks. Nature Plants. 2016;2:16150. https://doi.org/10.1038/nplants.2016.150.

55. Wu C-C, Wei F-J, Chiou W-Y, Tsai Y-C, Wu H-P, Gotarkar D, Wei Z-H, Lai M-H, Hsing Y-LC. Studies of rice Hd1 haplotypes worldwide reveal adaptation of flowering time to different environments. PLoS One. 2020;15:e0239028. https://doi.org/10.1371/journal.pone.0239028.

56. Corrado G, Rao R. Towards the genomic basis of local adaptation in landraces. Diversity. 2017;9:51. https://doi.org/10.3390/d9040051.

\section{Publisher's Note}

Springer Nature remains neutral with regard to jurisdictional claims in published maps and institutional affiliations. 